\title{
Pre-Agreement Assessment as a Responsible \\ Lending Tool in South-Africa, the EU and \\ Belgium: Part 1
}

\section{CM van Heerden* and R Steennot ${ }^{\star \star}$}

\section{P.E.R}

Pioneer in peer-reviewed, open access online law publications

Authors

Corlia M van Heerden and

Reinhard Steennot

Affiliation

University of Pretoria

South Africa

Ghent University

Belgium

Email

corlia.vanheerden@up.ac.za

Reinhard.Steennot@UGent.be

Date of submission

\section{July 2017}

Date published

19 March 2018

\section{Editor Dr A Gildenhuys}

How to cite this article

Van Heerden CM and Steennot R "Pre-Agreement Assessment as a Responsible Lending Tool in

South-Africa, the EU and Belgium: Part 1" PER / PELJ 2018(21) - DOI http://dx.doi.org/10.17159/17273781/2018/v21i0a2950

\section{Copyright}

DOI

http://dx.doi.org/10.17159/17273781/2018/v21i0a2950

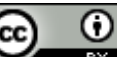

1 12018/v21ioazgso

\begin{abstract}
Responsible lending has become a very pertinent issue on the agenda of credit regulators across the globe who seek to combat the causes of consumer over-indebtedness. In this context the use of "pre-agreement assessment" as a tool to filter out those instances where, based on a consumer's creditworthiness or ability to repay, credit should not be granted to such a consumer, is a feature common to the lending regimes of various jurisdictions. This contribution consists of two parts: Part 1 provides a critical discussion of the reckless credit provisions of the National Credit Act 34 of 2005. Part 2 details the responsible lending measures contained in the EU Consumer Credit Directive and the EU Mortgage Credit Directive and provides an appraisal of the responsible lending measures introduced by Belgium, being a jurisdiction that has always been very pro-active in the context of consumer credit protection.
\end{abstract}

\section{Keywords}

Responsible lending, reckless credit granting, pre-agreement assessment, affordability, creditworthiness 


\section{Introduction}

Credit is part of the lives of millions of consumers across the globe. As much as it enables them to acquire goods it is unfortunately also the cause of many of their woes, because many consumers end up being over-indebted and unable to repay the credit on the agreed terms and conditions. Accordingly the global growth in credit consumerism has also given rise to the need to protect these credit consumers - not only against unscrupulous lenders but often also against themselves. This need for consumer protection in the credit sphere has sparked the development of responsible lending rules as a measure to prevent credit from being extended to consumers who are unable to afford it. ${ }^{1}$ Inherent in the notion of responsible lending is also the concept of responsible borrowing, which is encouraged by preventing consumers, through certain legislative measures, from overextending themselves financially. ${ }^{2}$ Responsible lending practices cover a wide array of measures such as consumer education and the promotion of financial literacy, responsible marketing, the provision of information, explanation and advice to consumers before the conclusion of the contract, the regulation of the cost of credit, the prohibition of certain lending practices and the pre-agreement screening of consumers to determine their ability to repay the debt as per the terms and conditions of the agreement (that is, creditworthiness or affordability). In the context of responsible lending (and borrowing) the use of "pre-agreement assessment" as a tool to filter out those instances where, based on a consumer's creditworthiness or ability to repay, credit should not be granted, is a feature common to the lending regimes of various jurisdictions. ${ }^{3}$

The purpose of this contribution is to provide an overview of the nature and extent of pre-agreement assessment as a responsible lending tool in South Africa and the EU, and specifically Belgium as an EU member state with a progressive approach to the protection of credit consumers. Pertinent aspects regarding the pre-agreement assessment approaches in these jurisdictions will be discussed and compared and certain salient observations will be made that could possibly spark further debate as to appropriate features of a pre-agreement assessment model that could

\footnotetext{
* $\quad$ Corlia M van Heerden. B Proc (UP) LLB (UP) LLM (Unisa) LLM (UP) LLD (RAU). Professor, Department of Mercantile Law, University of Pretoria. Email: corlia.vanheerden@up.ac.za.

** Reinhard Steennot. LLM (Ghent) LLD (Ghent). Professor, Department of Interdisciplinary Study of Law, Private Law and Business Law, Ghent University. Email: Reinhard.Steennot@UGent.be.

1 World Bank 2013 http://www.Siteresources.worldbank.org/.../Resources/.../ Responsible-Lending-Paper.pdf Van Heerden and Renke 2015 IIR 67.

For examples, see Wilson International Responses to Issues of Credit.
} 
efficiently prevent or curb irresponsible lending and its ill-consequence, consumer over-indebtedness.

This contribution will consist of two parts: Part One will contain a discussion of the provisions in the National Credit Act 34 of 2005 pertaining to preagreement assessment and reckless credit. Part Two will address the legal framework for pre-agreement assessment and responsible lending in the EU and Belgium and will conclude with a comparative discussion of the measures pertaining to pre-agreement assessment in South Africa, the EU and Belgium.

\section{Responsible lending and pre-agreement assessment in South Africa}

\subsection{Introduction}

The substantive and procedural landscape of credit regulation in South Africa underwent a massive change with the enactment of the National Credit Act 34 of 2005 (NCA) that came into full effective operation on 1 June 2007. This Act replaced the outdated legislation that previously provided the framework for credit regulation, namely, the Credit Agreements Act, ${ }^{4}$ that regulated credit instalment sale and lease agreements in respect of movables, and the Usury $A c t{ }^{5}$ that regulated the same agreements and money lending transactions. The NCA is a comprehensive and compact piece of legislation that regulates a much wider scope of credit agreements than its predecessors and places no monetary cap on the amounts of the transactions regulated. ${ }^{6}$ South Africa does not have separate legislative frameworks for the regulation of consumer credit and mortgage credit (as is the case in the EU and Belgium) and accordingly only one set of rules as contained in the NCA applies across the board to all types of credit agreements, including mortgage credit. However, in certain instances the Act does provide for deviations or exceptions based on the type of agreement, or contains provisions that apply only to certain types of credit agreements.

Credit Agreements Act 75 of 1980.

Usury Act 73 of 1968.

As discussed in para 3.2 below. The National Credit Act 34 of 2005 (the NCA), however, does not apply to large credit agreements entered into by juristic person consumers. A juristic person is defined in $\mathrm{s} 1$ of the NCA include a partnership, association or other body of persons, corporate or unincorporated, or a trust if it has three or more individual trustees or the trust is itself a juristic person. A stokvel, which term refers to an informal savings scheme among a number of natural persons, is, however, expressly excluded from this definition. 


\subsection{Scope of application}

As regards its application ratione personae the NCA applies to "consumers" 7 who may either be natural persons or small juristic persons regardless of whether they enter into credit agreements for private or business purposes. ${ }^{8}$ However, it is to be noted that the purpose of the Act is not to protect "big business", ${ }^{9}$ and accordingly the application of the Act in so far as it relates to juristic person consumers is limited, as discussed in more detail below. It is to be noted further that the Act provides a sui generis definition of "juristic" persons that includes entities such as partnerships and trusts in certain instances, despite the fact that generally those entities are not otherwise regarded as juristic persons.

The NCA refers to the party who extends credit as the "credit provider"10 and mandates the registration of credit providers with the National Credit Regulator, being the entity responsible for the enforcement of the Act. ${ }^{11}$

The "layered" application of the NCA ratione materiae is set out in section 4 read with sections 5 to 9 . The NCA applies to every credit agreement between parties dealing at arm's length and made within or having an effect within the Republic of South Africa. ${ }^{12}$ "Credit", when used as a noun, is

7 As per $\mathrm{s} 1$ of the NCA a "consumer", in respect of a credit agreement to which the NCA applies, means the party to whom goods or services are sold under a discount transaction, incidental credit agreement or instalment agreement; the party to whom money is paid, or credit granted, under a pawn transaction; the party to whom credit is granted under a credit facility; the mortgagor under a mortgage agreement; the borrower under a secured loan; the lessee under a lease; the guarantor under a credit guarantee; or the party to whom or at whose direction money is advanced or credit granted under any other credit agreement (governed by the NCA). Clearly, juristic persons cannot be said to enter into credit agreements for "private purposes".

$9 \quad$ See Standard Bank v Hunkydory Investments 188 (Pty) Ltd 20101 SA 634 (WCC).

10 As per $s 1$ of the NCA "credit provider" in respect of any credit agreement to which the NCA applies means the party who supplies goods or services under a discount transaction, incidental credit agreement or instalment agreement; the party who advances money or credit under a pawn transaction; the party who extends credit under a credit facility; the mortgagee under a mortgage agreement; the lender under a secured loan; the lessor under a lease; the party to whom an assurance or promise is made under a credit guarantee; the party who advances money or credit to another under any other credit agreement; or any other person who acquires the rights of a credit provider under a credit agreement after it has been entered into.

11 Section 40 of the NCA requires all credit providers to register, except persons who only provide "incidental credit". The National Credit Regulator (NCR), established in terms of $s 12$ of the NCA, registers credit providers. See further $s 13$ regarding the NCR's duties with regard to the development of an accessible credit market and $s$ 15 regarding its enforcement functions as well as s 16 , which sets out its duties with regard to research and public information.

12 Section 4(1) of the NCA. This application is subject to $s 5$ (which provides for the application of the NCA to incidental credit agreements) and $s 6$ (which provides for the limited application of the NCA to certain juristic persons). See further Otto and 
defined in the Act as a deferral of payment of money owed to a person or a promise to defer such payment; or a promise to advance or pay money to or at the direction of another person. ${ }^{13}$ "Agreement" includes an arrangement or understanding between or among two or more parties, which purports to establish a relationship in law between those parties. ${ }^{14}$ Thus it is essential to establish whether a specific agreement entered into in South Africa or having an effect in South Africa constitutes a "credit agreement" as provided for in the NCA. It should also be borne in mind that even if an agreement constitutes a credit agreement as defined in the NCA, the Act will not apply if the agreement was not concluded at arm's length. ${ }^{15}$

Three main types of credit agreements are regulated by the NCA, namely, credit facilities, ${ }^{16}$ credit transactions ${ }^{17}$ and credit guarantees. ${ }^{18}$ It is

Otto National Credit Explained ch 3; Stoop 2008 De Jure 352. (All references to sections hereinafter are to sections of the NCA, unless otherwise indicated.)

Section 1.

14 Section 1.

15 On the topic of arm's length s 4(2)(b) of the NCA specifically provides that in any of the following arrangements the parties are not dealing at arm's length: A shareholder loan or other credit agreement between a juristic person, as a consumer, and a person who has a controlling interest in that juristic person, as a credit provider; a loan to a shareholder or other credit agreement between a juristic person, as a credit provider, and a person who has a controlling interest in that juristic person, as a consumer; a credit agreement between natural persons who are in a familial relationship and are co-dependent on one another or where one is dependent upon the other; and any other arrangement in which a party is not independent of the other and consequently does not necessarily strive to obtain the utmost possible advantage out of the transaction; or that is of a type that has been held in law to be between parties who are not dealing at arm's length. See further Beets $v$ Swanepoel (NCHC) (unreported) case number 2150/09 of 5 October 2010; Friend $v$ Sendal 2015 1 SA 395 (GP).

16 In terms of $s 8(3)$ an agreement, irrespective of its form, but not including an agreement contemplated in s 8(2) or s 8(4)(6)(b), constitutes a "credit facility" if in terms of that agreement: (a) a credit provider undertakes to supply goods or services or to pay an amount or amounts, as determined by the consumer from time to time, to the consumer or on behalf of, or at the direction of, the consumer, and either to defer the consumer's obligation to pay any part of the cost of goods or services, or to repay to the credit provider any part of an amount or bill the consumer periodically for any part of the cost of goods or services, or any part of an amount; and (b) any charge fee or interest is payable to the credit provider in respect of any amount deferred or any amount billed and not paid within the time provided for in the agreement.

17 As per s 8(4) an agreement, irrespective of its form, but not including an agreement contemplated in s 8(2) as indicated below, constitutes a "credit transaction" if it is a pawn transaction or discount transaction; an incidental credit agreement; an instalment agreement; a mortgage agreement or secured loan; a lease; or "any other agreement, other than a credit facility or credit guarantee, in terms of which payment of an amount owed by one person to another is deferred, and any charge, fee or interest is payable to the credit provider in respect of the agreement or the amount that has been deferred" (the so-called "catch all credit agreement" as per $s$ 8(4)(f)).

18 As per s 8(5) an agreement, irrespective of its form, but not including an agreement contemplated in s 8(2) as indicated below, constitutes a "credit guarantee" if, in terms 
expressly provided that a policy of insurance or credit extended by an insurer solely to maintain the payment of premiums on a policy of insurance, a lease of immovable property or a transaction between a stokvel and a member of that stokvel in accordance with the rules of that stokvel, irrespective of their form, are not credit agreements for the purposes of the NCA. ${ }^{19}$

The three types of credit agreements mentioned above fall into further categories, namely small, ${ }^{20}$ intermediate ${ }^{21}$ and large ${ }^{22}$ credit agreements, generally depending on the amount of credit involved. This distinction influences a number of aspects such as certain disclosure requirements and exemption from the application of the Act of agreements entered into by certain juristic persons.

The following agreements are expressly exempt from the application of the Act: 23

(a) a credit agreement in terms of which the consumer is a juristic person whose asset value or annual turnover, together with the combined asset value or annual turnover of all related ${ }^{24}$ juristic persons, at the time the agreement is made, equals or exceeds R1 million (hereinafter

of that agreement, a person undertakes or promises to satisfy upon demand any obligation of another consumer in terms of a credit facility or a credit transaction to which the NCA applies.

19 Section 8(2).

20 In terms of $s$ 9(2) read with the Determination of Thresholds Regulations (GN 713 in GG 28893 of 1 June 2006) (the Thresholds Regulations) a credit agreement is a small agreement if it is a pawn transaction; a credit facility with a limit falling at or below R15 000 and any other credit transaction, except a mortgage agreement, and the principal debt under that transaction or guarantee falls at or below R15 000 .

21 In terms of $s$ 9(3) read with the Thresholds Regulations a credit agreement qualifies as an intermediate agreement if it is a credit facility with a credit limit that falls above R15 000 or any credit transaction except a pawn transaction or a mortgage agreement, and the principal debt under that transaction or guarantee falls between R15 000 and R250 000

Per s 9(3) read with the Thresholds Regulations "large credit agreements" are mortgage agreements or any other credit transaction except a pawn transaction, if the principal debt under that transaction or guarantee falls at or above R250 000 . Pawn agreements will thus always be small credit agreements and mortgage agreements will always be large agreements whilst it should be noted that credit facilities can be small or intermediate agreements but are not treated as large agreements even though they may fall within the monetary threshold for large agreements. "Exempt" transactions as per s 4(1)(a)-(d) must be distinguished from credit agreements to which the Act expressly does not apply as per s 8(2) as set out above. According to $s 4(2)(d)$, a juristic person is related to another juristic person if one of them has direct or indirect control over the whole or part of the business of the other; or a person has direct or indirect control over both of them. 
referred to as a "large" juristic person); or the State; or an organ of State; 25

(b) a large agreement in terms of which the consumer is a juristic person whose asset value or annual turnover is, at the time the agreement is made, below R1 million ${ }^{26}$ (hereinafter referred to as a "small" juristic person);

(c) a credit agreement in terms of which the credit provider is the Reserve Bank of South Africa; ${ }^{27}$ or

(d) a credit agreement in respect of which the credit provider is located outside the Republic, approved by the Minister on application by the consumer in the prescribed manner and form. ${ }^{28}$

Note should also be taken of section $4(2)(\mathrm{c})$, which provides that the NCA applies to a credit guarantee only to the extent that the Act applies to a credit facility or credit transaction in respect of which the credit guarantee is granted. This effectively means that if the credit transaction or credit facility in respect of which the credit guarantee is granted falls outside the application of the NCA, the Act will also not apply to the credit guarantee. Thus the surety in such an instance will not be able to rely on the provisions of the NCA for protection. ${ }^{29}$

It is further provided that the application of the NCA extends to a credit agreement or proposed credit agreement irrespective of whether the credit provider resides or has its principal office within or outside the Republic, or (subject to section 4(1)(c)) is an organ of state, an entity controlled by an organ of state or an entity created by any public regulation or the Land and Agricultural Development Bank. ${ }^{30}$ Also, if the NCA applies to a credit agreement, it continues to apply to that agreement even if a party to that

\footnotetext{
25 Section 4(1)(a).

26 Section 4(1)(b). It should be noted that the asset value or annual turnover of related juristic persons is not taken into account for the purposes of this specific exemption.

27 Section 4(1)(c).

28 Section 4(1)(d). See reg 2 of the Thresholds Regulations for the prescribed manner and Form 1 for the prescribed form.

29 As the subsection provides that the Act applies to a credit guarantee only to the extent that the Act applies to the credit facility or credit transaction in respect of which the credit guarantee is granted, it is further submitted that a natural person consumer who stood surety for a juristic person to whom the Act applies, eg in respect of an intermediate credit transaction entered into by a small juristic person, will not be able to rely on the provisions of the Act relating to reckless credit and over-indebtedness as those provisions do not apply to juristic persons and the surety will be afforded the protection of the Act only to the extent that the Act applies to the underlying agreement. 
agreement ceases to reside or have its principal office within the Republic and it applies in relation to every transaction, act or omission under that agreement, whether that transaction, act or omission occurs within or outside the Republic. ${ }^{31}$

From the aforementioned it is thus clear that whereas the Act will not apply to credit agreements entered into with large juristic persons, as indicated in section $4(1)(a)(i)$ or to large credit agreements, such as for example mortgage bonds entered into by small juristic person consumers, the Act in fact will apply to small and intermediate credit agreements entered into by small juristic person consumers. However, such application to small juristic persons is limited by section 6 of the NCA, which indicates that the following provisions of the Act do not apply to a credit agreement or proposed credit agreement in terms of which the consumer is a juristic person: Chapter 4 , Parts $C$ and $D$, which deals with credit marketing practices and overindebtedness ${ }^{32}$ and reckless credit ${ }^{33}$ respectively; Chapter 5 , Part $A$, section 89(2)(b), which deals with an agreement resulting from negative option marketing; Chapter 5, Part A, section 90(2)(0), which deals with agreements at a variable interest rate; and Chapter 5 , Part $\mathrm{C}$, which deals with the consumer's liability, interest, charges and fees.

As a result of the aforesaid limited application of the NCA to small juristic persons who enter into small and intermediate credit transactions, such juristic persons (and by virtue of section 4(2)(b) natural persons who stood surety for the credit extended to these juristic persons) enjoy considerably fewer benefits under the NCA and will, for instance, not be able to access the debt relief provisions of the Act in respect of reckless credit and overindebtedness.

\subsection{Responsible lending}

A glaring lacuna in the outdated credit dispensation prior to the NCA was its failure to provide effective protection against consumer over-indebtedness and to address irresponsible lending practices. ${ }^{34}$ When the new, more comprehensive framework for credit regulation in terms of the NCA was drafted it therefore was proposed that it should have a distinct focus on the regulation of predatory lending practices that contributed to consumer over-

31 Section 4(4)(a) and (b). See further s 4(5) for "exemptions" relating to cheques and charges against credit facilities.

32 See 579.

33 See $\mathrm{s} 80$.

34 See in general DTI Consumer Credit Law Reform. Also see Goodwin-Groen and Kelly-Louw 2006 http://www.finmark.org.za/wp-content/uploads/2016/01/Rep_NCA AccesstoFinance_2006.pdf; and Renke Evaluation of Debt Prevention Measures. 
indebtedness. ${ }^{35}$ One of the hallmarks of the NCA accordingly is the wide range of responsible lending measures it introduced in the context of credit granting, which either directly or indirectly function as mechanisms to prevent consumer over-indebtedness. ${ }^{36}$ As such the NCA inter alia imposes strict obligations regarding the disclosure of information in the form of a preagreement statement and quotation; disclosure requirements relating to costs; a statutory in duplum rule that prevents the cost of credit from spiralling out of control and locking consumers into debt traps, and expressly prohibits "reckless credit" granting. ${ }^{37}$

The most pro-active responsible lending measure introduced by the NCA is a duty to conduct a pre-agreement assessment prior to entering into a credit agreement to establish whether the consumer will be able to afford the said credit. This pre-agreement assessment obligation imposed on credit providers specifically serves as a "filter" to prevent irresponsible credit granting, which is one of the root causes of consumer over-indebtedness. ${ }^{38}$ The pre-agreement assessment obligation accordingly operates as basis of flagging credit extension as "reckless" in three instances set out in section 80 of the Act.

The first type of reckless credit granting for the purposes of the NCA refers to the situation where the credit provider extended credit without conducting any prior pre-agreement assessment. ${ }^{39}$ Any credit so extended is per se reckless, as the credit provider's failure to conduct a pre-agreement assessment before extending credit to the consumer is inexcusable. ${ }^{40}$ The second type of reckless credit granting occurs where, even though the credit provider did conduct a pre-agreement assessment, it disregarded the fact that the preponderance of available information indicated that the consumer was generally ignorant regarding the risks, costs and obligations under a credit agreement. ${ }^{41}$ The third type of reckless credit refers to the situation where, despite the fact that a pre-agreement assessment was conducted which indicated that the granting of credit under the specific credit

35 See Minister of Trade and Industry 2005 http://www.gov.za/sites /www.gov.za/files/b18-05_0.pdf.

36 Section 79 provides that a consumer is over-indebted if "the preponderance of available information at the time a determination is made indicates that the particular consumer is or will be unable to satisfy in a timely manner all the obligations under all the credit agreements to which the consumer is a party, having regard to the consumer's - (a) financial means, prospects and obligations; and (b) probable propensity to satisfy in a timely manner all the obligations under all the credit agreements to which the consumer is a party, as indicated by the consumer's history of debt repayment".

37 See Renke Evaluation of Debt Prevention Measures for a detailed discussion.

$38 \quad$ Van Heerden and Renke 2015 IIR 67.

39 Section $80(1)(\mathrm{a})$.

40 The financial position of the consumer is irrelevant to this type of reckless credit.

41 Section $80(1)(b)(i)$. 
agreement would cause the consumer to become over-indebted, the credit provider disregarded such information and nevertheless extended the specific credit to the consumer, who could clearly not afford it. ${ }^{42}$ It is especially in the context of the third type of reckless credit that the significance of a proper pre-agreement affordability assessment is clear. It is also important to note that the reckless credit extension as envisaged by section 80 must have occurred at the time when the credit was extended ${ }^{43}$ - thus a determination of whether credit was granted recklessly, as contemplated by the NCA, entails a "set point" determination that is conducted with regard to the time of conclusion of the specific credit agreement. ${ }^{44}$ Case law has held that the onus to prove that reckless credit was extended in a specific instance rests on the person alleging that the specific credit was extended recklessly. ${ }^{45}$

As pointed out in the discussion above of the application of the NCA, the debt relief provisions in the Act pertaining to reckless credit and overindebtedness, as provided for in Part D of Chapter 4, are aimed at natural persons only and do not extend to juristic persons. ${ }^{46}$ Also, where a natural person has stood surety for a large juristic person (as per section 4(1)(a)) or a small juristic person who entered into a large credit agreement (as per section 4(1)(b)), such a natural person will be precluded from relying on the Act's provisions relating to reckless credit and over-indebtedness. Reckless credit granting can be raised in respect of a wide range of credit agreements, secured and unsecured, but not in respect of a school loan or a student loan; an emergency loan; a public interest credit agreement; a

42 Section $80(1)(\mathrm{b})(\mathrm{ii})$. It is submitted that it is implied in the context of $\mathrm{s} 80$ that this provision should be interpreted broadly also to mean that where the assessment shows that the consumer is already over-indebted even before taking up the proposed credit, granting him any further credit (that would thus make him even more over-indebted) would be reckless.

43 Authors' emphasis.

44 Section 80(2) provides that when a determination is to be made whether or not a credit agreement is reckless, the person making the determination must apply the criteria for reckless credit as contained in $s 80(1)$ as they existed at the time the agreement was made and without regard to the ability of the consumer to meet the obligations under the agreement or understand or appreciate the risks, costs and obligations under the proposed credit agreement at the time that the determination is being made. This means that if the consumer since entering a reckless credit agreement has become able to afford the credit or educated as to his risks, costs and obligations under the agreement, this does not negate the fact that the credit, at the time of the conclusion of the agreement was extended recklessly. Thus the granting of reckless credit cannot be remedied or ratified ex post the conclusion of the agreement. See further Van Heerden and Beyers 2016 JIBLR 446-463.

45 SA Taxi Securitization (Pty) Ltd v Mbatha 20111 SA 310 (GSJ); Absa Bank Ltd v Potgieter (ECPE) (unreported) case number 2344/2013 of 31 January 2017.

46 Gestalt Fund Managers (Pty) Ltd v Secura Systems (Pty) Ltd 2015 JDR 1284 (GJ) para 15. 
pawn transaction; an incidental credit agreement or a temporary increase in the credit limit under a credit facility. ${ }^{47}$

\subsection{Pre-agreement assessment as a measure to prevent reckless credit granting}

The pre-agreement assessment duty is set out in section 81(2)(a). It prohibits a credit provider from entering into a credit agreement without first taking reasonable steps to assess the proposed consumer's:

(i) general understanding and appreciation of the risks and costs of the proposed credit, and of his rights and obligations under a credit agreement;

(ii) debt repayment history as a consumer under credit agreements; and

(iii) existing financial means, prospects and obligations. ${ }^{48}$ In terms of section 81(2)(b), if the consumer applies for credit for a commercial purpose, the credit provider must assess whether there is a reasonable basis to conclude that such a commercial purpose may prove to be successful. ${ }^{49}$

At this stage it should be pointed out that despite the provision in section 69 of the NCA that the National Credit Regulator must establish and maintain a "national register of credit agreements", to date no such register has been established and accordingly credit providers have to consult databases that are being kept by credit bureaux in order to obtain information on a consumer's credit profile and debt repayment history. All credit bureaux in South Africa have to register with the National Credit Regulator in accordance with section 43 of the NCA, so at least it can be remarked that these credit bureaux are well-regulated and accordingly that the information that they keep is generally correct and of a good standard. ${ }^{50}$ However, it has

$47 \quad$ Section $78(2)$.

48 Section 78(3) provides that "financial means, prospects and obligations" with respect to a consumer or prospective consumer include: "(a) income, or any right to receive income, regardless of the source, frequency or regularity of that income, other than income that the consumer or prospective consumer receives, has a right to receive, or holds in trust for another person; (b) the financial means, prospects and obligations of any other adult person within the consumer's immediate family or household, to the extent that the consumer, or prospective consumer, and that other person customarily - (i) share their respective financial means; and (ii) mutually bear their respective financial obligations; and (c) if the consumer has or had a commercial purpose for applying for or entering into a particular credit agreement, the reasonably estimated future revenue flow from that business purpose".

49 Section 81(2)(b). See further Desert Star Trading 145 v No 11 Flamboyant Edleen CC 20112 SA 266 (SCA) paras 14, 15. Van Heerden and Renke 2015 IIR 67. 
to be pointed out that in South Africa the government from time to time declares credit amnesties that result in the removal of certain information from credit bureaux which, it is submitted, may compromise the completeness of credit bureaux information, its ability to reflect the consumer's complete credit history, and how he has conducted himself in the past with regard to his use of credit. 51

South African consumers are also obliged to co-operate in the prevention of reckless credit granting: section 81(1) provides that when applying for credit, and while that application is being considered by a credit provider, the prospective consumer must "fully and truthfully" answer any requests for information made by the credit provider as part of the pre-agreement assessment. It is a complete defence to an allegation of reckless credit if the credit provider establishes that the consumer failed to answer fully and truthfully any such request for information made by the credit provider and if a court or the National Consumer Tribunal ${ }^{52}$ determines that the consumer's failure to do so materially affected the ability of the credit provider to make a proper assessment. ${ }^{53}$

Although not stated in as many words, a proper reading of the NCA indicates that where a credit provider for instance wants to give a consumer an increase in a credit facility or wants to advance a further amount to a consumer under a mortgage loan secured by a further mortgage bond, the credit provider has to conduct a fresh section 81(2) assessment, evaluating the consumer's current financial situation as at the time of the extension of the extra ("new") credit and thus effectively re-assessing the consumer's ability to afford the extra credit.

The aspect of pre-agreement assessment in terms of the NCA has undergone significant reform since its inception: apart from stating that a pre-agreement assessment is mandatory and that it has to be conducted by means of reasonable steps to assess the three aspects mentioned in section 81(2) and imposing a "truthfulness obligation on the consumer", the NCA initially did not prescribe any specific assessment model that had to be applied by credit providers in order to comply with the pre-assessment duty imposed by section $81 .{ }^{54}$ It was originally provided that a credit provider may determine for itself the evaluative mechanisms or models and

$51 \quad$ Van Heerden and Renke 2015 IIR 67; Kelly-Louw 2015 De Jure 92.

52 The Tribunal was established in terms of $s 26$ of the NCA. See $s 27$ regarding its functions and s 83 as well as ss 149-152 regarding the orders it can make.

53 Section 81(4). For a detailed discussion of this defence see Van Heerden and Boraine 2011 De Jure 396-397 and 400; Kelly-Louw 2014 SA Merc LJ 24ff. Also see Horwood v Firstrand Bank Ltd 2011 ZAGPJHC 121 (21 September 2011).

54 Van Heerden and Renke 2015 IIR 76. 
procedures to be used in meeting its assessment obligations under section 81 as long as they resulted in a fair and objective assessment. ${ }^{55}$ It was further provided that the National Credit Regulator could publish nonbinding guidelines proposing evaluative mechanisms, models and procedures for the purposes of pre-agreement assessment. ${ }^{56}$ No guidelines were published until May 2013, however, with the result that credit providers to a large extent had a carte blanche in how they structured and conducted their section 81 assessments. Due to the lack of guidance in the Act and the lack of any guidelines published by the National Credit Regulator, the courts had to assist in providing some guidance on when a proper assessment for the purposes of section 81 could be said to have been conducted. ${ }^{57}$

In Horwood $v$ Firstrand Bank $L t d^{58}$ it was held that, in the light of the wording of sections 81(2) and 82(1), whether or not a credit grantor has taken the required reasonable steps to meet its assessment obligations is to be determined objectively on the facts and circumstances of any given case. In SA Taxi Securitisation (Pty) Ltd v Mbatha, ${ }^{59}$ however, the court remarked that

... while one purpose of the National Credit Act is to discourage reckless credit, the Act is also designed to facilitate access to credit by borrowers who were previously denied such access. Consequently, an over-critical armchair approach by the court towards credit providers when evaluating reckless credit, or the imposition of excessive penalties upon lenders who have recklessly allowed credit, would significantly chill the availability of credit especially to the less affluent members of our society.

55 This provision had to be read with s 61(5), which provides that a credit provider may determine for itself any scoring or other evaluative mechanism or model to be used in managing, underwriting and pricing credit risk, provided that any such mechanism or model is not founded or structured upon a statistical or other analysis in which the basis of risk categorisation, differentiation or assessment is a ground of unfair discrimination prohibited in s 9(3) of the Constitution of the Republic of South Africa, 1996. The original s $82(1)$ was subject to s $82(2)(a)$, which provided that the National Credit Regulator could pre-approve the evaluative mechanisms, models and procedures to be used in terms of s 81 in respect of proposed developmental credit agreements.

56 If a credit provider repeatedly failed to meet its obligations under s 81 or customarily used evaluative mechanisms, models or procedures that did not result in a fair and objective assessment, the Regulator could in terms of s 82(4)(a) and (b) apply to the Tribunal for an order in terms of $s 82(4)$, requiring that credit provider to apply any guidelines published by the Regulator in terms of $s$ 82(2)(b) or any alternative guidelines consistent with prevalent industry practice.

$57 \quad$ Van Heerden and Renke 2015 IIR 77.

$58 \quad H o r w o o d v$ Firstrand Bank Ltd 2011 ZAGPJHC 121 (21 September 2011).

$59 \quad$ SA Taxi Securitisation (Pty) Ltd v Mbatha 20111 SA 310 (GSJ). 
In Absa Bank v COE Family Trust ${ }^{60}$ the credit provider relied on a particular clause in a mortgage loan agreement that was worded to constitute an acknowledgement that the defendants understood the risks and costs and the rights and obligations under the agreement. It was alleged that this agreement covered all the requirements for the prescribed assessment and further that it was not open to the defendants to raise a defence of reckless credit because if it was established in terms of section 81(4) that the consumer failed fully and truthfully to answer requests for information made by the credit provider, this was a complete "response" (defence) by the credit provider to the allegations of reckless credit made by the defendants. The court dismissed the matter after considering the clause and stating that there was no indication, other than the aforementioned clause, as to whether an actual request for information was made to any of the defendants by or on behalf of the plaintiff. Such a request would have ensured that the credit process was undertaken in terms of the threepronged set of inquiries contained in section 81 (2). It remarked that because it appeared that no assessment as contemplated by section 81 (2) had been conducted, the issue regarding whether the consumer answered truthfully or not as envisaged by section 81(4) became irrelevant.

The above interventions by the courts assisted in laying down certain broad guidelines regarding the section 81 assessment process. However, these guidelines were not entirely sufficient as they did not address the specific detail of how exactly the pre-agreement assessment had to be conducted and specifically how the consumer's affordability had to be assessed. Eventually, in November 2012 a joint media statement was issued by the Minister of Finance, the National Credit Regulator and the Chairperson of the Banking Association of South Africa (BASA), entitled "Ensuring Responsible Market Conduct for Bank Lending". ${ }^{61}$ It was agreed that a standard to measure affordability would be formulated which could then be incorporated into regulations as minimum standards. ${ }^{62}$ Subsequently the National Credit Regulator issued a public notice in May $2013^{63}$ in which certain broad draft affordability guidelines (not regulations as per the aforementioned Joint Statement) were proposed, namely that

\footnotetext{
$60 \quad$ Absa Bank v COE Family Trust 20123 SA 184 (WCC). See specifically paras 6-11.

61 Ministry of Finance 2012 http://www.treasury.gov.za/comm_media/press/ 2012/2012110101.pdf (hereafter referred to as the "Joint Statement").

62 Joint Statement 3.

63 See NCR 2013 http://www.ncr.org.za/press_release/Public\%20Notice\%20.pdf. Also see NCR 2010 http://www.ncr.org.za/pdfs/Circulars/Code\%20of\%20Conduct\% 20for\%20CPs.pdf.
} 
(a) credit applicants prove their claimed discretionary income when it is above the norm for a person with their gross income and that such norms be determined as a percentage of gross income bands;

(b) credit providers consider all the credit applicant's income, expenses and debt repayments when doing an affordability assessment;

(c) credit providers refrain from lending to the maximum of the consumer's discretionary income and leave a margin of at least 25 percent of their discretionary income for adverse changes in the economy or the consumer's circumstances (thus an "adversity buffer");

(d) credit providers use the credit applicant's current information as stored with one or more credit bureaux;

(e) credit providers process applications for credit within seven days from assessing an applicant's credit information as stored with credit bureaux; and

(f) credit providers share credit application information with credit bureaux to allow for better affordability assessments to be made by other credit providers and to reduce credit application fraud.

The May 2013 Draft Guidelines thus set out the broad approach that would underlie the eventual creation of a binding set of affordability regulations. More refined and comprehensive guidelines (not regulations) were published in September 2013.64 An important intervention subsequent to the September 2013 guidelines entailed the approval of the National Credit Amendment $A c t^{65}$ which, although approved, had not yet been put into operation pending the introduction inter alia of affordability assessment regulations (not merely guidelines). Section 48 of the NCA was amended to provide for the Minister of Trade and Industry, on the recommendation of the National Credit Regulator, ${ }^{66}$ to prescribe criteria and measures to determine the outcome ( $\mathrm{sic}$ ) of affordability assessments. ${ }^{67}$ Sections 82(1) and (2) of the NCA were replaced to provide that a credit provider may determine for itself the evaluative mechanisms or models and procedures

64 September 2013 Affordability Assessment Guidelines available at http://debtfreedigi.co.za/wp-content/uploads/2013/10/NCR-AffordabilityAssessment Guidelines.pdf. For a detailed discussion see Van Heerden and Renke 2015 IIR 7982.

$65 \quad$ National Credit Amendment Act 19 of 2014.

66 Section 24 of the National Credit Amendment Act 19 of 2014.

67 Section 15(c) of the National Credit Amendment Act 19 of 2014. Obviously the Minister cannot determine the outcome of these assessments but merely how the assessments must be conducted. 
to be used in meeting its assessment obligations under section 81, provided that any such mechanism, model or procedure results in a fair and objective assessment which must not be inconsistent with the affordability assessment regulations ${ }^{68}$ made by the Minister of Trade and Industry. ${ }^{69}$ As a result of the amendments introduced by the National Credit Amendment Act, the final Affordability Assessment regulations that came into operation in September 2015 as discussed below are now binding subordinate legislation that constitutes the minimum standards which credit providers have to comply with in conducting the pre-agreement assessment envisaged by section 81.70

After the publication of the approved National Credit Amendment Act but prior to its being put into operation, a comprehensive set of draft regulations on various matters including regulations on affordability assessment was published in August 2014 for public comment. ${ }^{71}$ On 13 March 2015 the National Credit Amendment Act was eventually put into operation together with the final "National Credit Regulations including Affordability Assessment Regulations". ${ }^{72}$ The coming into operation of the Final Affordability Assessment Regulations was, however, postponed for a further six months until 13 September 2015 to afford credit providers the opportunity to align their assessment models with the Affordability Regulations. $^{73}$

In line with section 78(1), the Final Affordability Assessment Regulations apply only when credit agreements governed by the NCA are entered into by natural person consumers. Certain credit agreements are exempt from the application of the regulations ${ }^{74}$ but no distinction is made between

68 Authors' emphasis.

69 Section 24 of the National Credit Amendment Act 19 of 2014. Also see s 15(b), which amends $s 48$ of the NCA to the effect that with regard to the registration of credit providers the compliance by a credit provider with the affordability assessment regulations made by the Minister on the recommendation of the National Credit Regulator may inter alia be considered. Where allegations of reckless credit are made based on a s 81 assessment which was conducted prior to 13 September 2015 (being the date that the final Affordability Assessment regulations took effect) the original considerations where no binding guidelines for the assessment existed will apply.

71 GN R597 in GG 37882 of 1 August 2014.

72 National Credit Regulations including Affordability Assessment Regulations published in GN R202 in GG 38557 of 13 March 2015.

73 GN 756 in GG 39127 of 21 August 2015 (the Final Affordability Assessment Regulations).

74 See reg $23 \mathrm{~A}(2)$ of the Final Affordability Assessment Regulations. These exempt agreements include a developmental credit agreement; a school loan or a student loan; a public interest credit agreement; a pawn transaction; an incidental credit agreement; an emergency loan; a temporary increase under a credit facility; a 
secured and unsecured credit agreements. ${ }^{75}$ In terms of the Regulations a credit provider is obliged to take practicable ${ }^{76}$ steps to assess the consumer or joint consumers'77 discretionary income to determine whether the consumer has the financial means and prospects to pay the proposed credit agreements. ${ }^{78}$ The credit provider must validate the consumer's gross income. The Regulations specify the specific documentation to be obtained for such verification with regard to consumers who receive a salary from an employer, those who do not, and consumers who are self-employed. ${ }^{79}$

Regulation $23 \mathrm{~A}(8)$ requires the credit provider to make a calculation of the consumer's existing financial means, prospects and obligations. When calculating the consumer's existing financial obligations the Regulations compel the credit provider to utilise a table of certain minimum expense norms (Table 1) contained in the regulations (which table is broken down by monthly gross income for certain specified income bands), namely:

unilateral credit limit increase in a credit facility in terms of ss 119(1)(c), 119(4) and 119(5) of the Act; a pre-existing credit agreement in terms of Schedule 3 Item 4(2) of the Act; any change to a credit agreement and/or any deferral or waiver of an amount under an existing credit agreement in accordance with s 95 of the Act and mortgage credit agreements that qualify for the Finance Linked Subsidy Programmes developed by the Department of Human Settlements and credit advanced for housing that falls within the thresholds set from time to time. The exemptions in the Regulations basically mirror the exempt agreements mentioned in s 78(2) but also add specific instances of low-cost mortgage credit as aforementioned.

75 The September 2013 guidelines distinguished between secured and unsecured credit. See Van Heerden and Renke 2015 IIR 80.

76 There appears to be a discrepancy between the NCA and the regulations in this regard as $\mathrm{s} 81$ (2) of the NCA requires the credit provider to take "reasonable" steps to assess the aspects mentioned in $\mathrm{s} 81(2)$.

"Joint consumers" are defined in the Final Affordability Assessment Regulations as "consumers that are co-principal debtors who are jointly and severally liable with regard to the same credit agreement and apply jointly for the credit agreement excluding the surety or a credit guarantor under a credit guarantee". Regulation 23A(3) of the Final Affordability Assessment Regulations.

79 Regulation $23 \mathrm{~A}(4)$ of the Final Affordability Assessment Regulations. Where the consumer's monthly gross income shows material variance, reg $23 \mathrm{~A}(5)$ provides that the average gross income over the period of not less than three pay periods preceding the credit application must be used. 
Table 1: NCR minimum expense norms

\begin{tabular}{|l|l|l|l|l|}
\hline $\begin{array}{l}\text { Income } \\
\text { Band }\end{array}$ & $\begin{array}{l}\text { Minimum } \\
\text { income }\end{array}$ & $\begin{array}{l}\text { Maximum } \\
\text { income }\end{array}$ & $\begin{array}{l}\text { Minimum } \\
\text { monthly } \\
\text { fixed factor }\end{array}$ & $\begin{array}{l}\text { Monthly fixed } \\
\text { factor: percentage } \\
\text { of amount above } \\
\text { band minimum }\end{array}$ \\
\hline 1 & R0.00 & R800.00 & R0.00 & $100 \%$ \\
\hline 2 & R800.01 & R6 250.00 & R800.00 & $6.75 \%$ \\
\hline 3 & R6 250.01 & R25 000.00 & R1 167.88 & $9.00 \%$ \\
\hline 4 & R25 000.01 & R50 000.00 & R2 855.28 & $8.20 \%$ \\
\hline 5 & R50 000.01 & Unlimited & R4 905.38 & $6.75 \%$ \\
\hline
\end{tabular}

According to Regulation $23 \mathrm{~A}(10)$ the following methodology must be applied when using the Table: The credit provider must ascertain the consumer's gross income; thereafter statutory deductions and minimum living expenses must be deducted to arrive at a net income, which must be allocated for the payment of debt instalments. When existing instalments are taken into account, the credit provider must calculate the consumer's discretionary income that will be available to enable the consumer to satisfy any new debt. It is to be noted that the credit provider may on an exceptional basis, where justified, accept the consumer's declared minimum expenses which are lower than those set out in Table 1, provided that the credit provider sees to it that a questionnaire, which is set out in Schedule 1 to the Regulations, is completed by the consumer or joint consumers to serve as proof that the specific consumer's living expenses are lower than prescribed by Table $1 .{ }^{80}$ However, as discussed in more detail below, the practical application of Table 1, as it currently appears in the Final Affordability Regulations, is problematic.

Regulation $23 \mathrm{~A}(10)$ has to be read with Regulation $23 \mathrm{~A}(12)$, which obliges the credit provider, when conducting an affordability assessment, to calculate the consumer's discretionary income; to take into account all monthly debt repayment obligations in terms of credit agreements as reflected on the consumer's credit profile held by a registered credit bureau;

80 Regulation 23A(11) of the Final Affordability Assessment Regulations. The words "the questionnaire set out in the Schedule, as issued from time to time" appear to imply that the questionnaire may be amended from time to time. 
and to take into account maintenance payments and other necessary expenses.

In line with section 81(2) the mandatory consultation of credit bureaux records prior to extending credit to a consumer is a prominent feature of the pre-agreement assessment process - hence the emphasis put on this requirement by the Regulations that further oblige the credit provider to take into account the consumer's debt repayment history (not merely how many transactions are listed in his name) as a consumer under credit agreements as contemplated in section $81(2)(a) .{ }^{81}$ The credit provider must ensure that this requirement is performed within seven business days immediately prior to the initial approval of credit or the increasing of a credit limit, and within fourteen business days in the case of mortgages. ${ }^{22}$ Obviously, the credit provider will also have to submit proof that he complied with this requirement. However, it can be observed at this stage that it does not make sense why there should be a distinction between mortgage credit and other credit in so far as the consultation period of credit bureaux is concerned. If the purpose of the credit bureau check is to ascertain the extent of the consumer's existing debt obligations it would make more sense to conduct such a credit bureau consultation as close to the conclusion of the proposed credit agreement as possible, to minimise the risk that the consumer in the meantime enters into other credit that may compromise his repayment ability.

In South Africa it often happens that consumers take up so-called "consolidation loans" in terms of which they borrow an amount of money that is large enough to settle their smaller credit agreements so that they then effectively rid themselves of those smaller credit agreements and various credit providers. Accordingly the Regulations provide that in order to avoid "double counting" in calculating the consumer's discretionary income where a credit agreement is entered into on a substitutionary basis in order to settle one or more existing credit agreements, a credit provider must record that the credit being applied for is to replace other existing credit agreements. ${ }^{83}$ In practical terms this means that the credit provider's affordability calculation must not deduct the instalments for those small agreements from the consumer's nett income as those amounts will be included in the monthly instalment of the new proposed consolidation loan. In addition the Final Affordability Assessment Regulations, echoing the

\footnotetext{
81 This makes sense as such a history will reveal the consumer's exposure in terms of existing credit obligations, which plays a pivotal role in determining affordability.

82 Regulation 23A(13)(a) and (b) of the Final Affordability Assessment Regulations.

83 Regulation 23A(14)(a) of the Final Affordability Assessment Regulations. In addition, reg $23 A(14)(B)$ states that the credit provider must take practicable steps to ensure that such credit is properly used for such purposes.
} 
provisions of the NCA that already exist in this regard, again mandate the disclosure of the credit cost multiple and the total cost of credit to the consumer. ${ }^{84}$

As indicated above, responsible lending also requires the co-operation of the consumer. The Regulations therefore also impose certain obligations on the consumer: he or she must accurately disclose to the credit provider all his or her financial obligations to enable the credit provider to conduct the affordability assessment and must for that purpose also provide authentic documentation to the credit provider. ${ }^{85}$

At this stage the South African courts have not yet had the opportunity to engage extensively with the augmented pre-agreement assessment process as mandated by section 81(2) read with the Final Affordability Regulations, as these affordability regulations have come into effect only recently and their application is still in a "honeymoon phase". However, it is clear that the pre-agreement process in South Africa has to be conducted within the parameters of the legal framework as indicated above. Even though the NCA still provides that credit providers may use their own evaluative methods, they do not have much discretion on how to do the assessment because of the strict obligations imposed by the Final Affordability Assessment Regulations. It is also not improbable that the Regulations themselves may be challenged in court due to certain problematic aspects. It is important to point out here that the mandatory utilisation of Table 1 was first introduced in the September 2013 guidelines where annual income was used as basis for the selection of income bands contained in the Table. In the said guidelines an example was provided as to the practical application of the Table, which indicated that, as a general guideline, should the prospective consumer have an annual gross income of R24 000 the credit provider may not accept annual necessary expenses of less than R14 400 (being the amount indicated as annual minimum living expenses for that income band) plus R648 (being 6.75\% of R9 600). The annual income bands and annual living expenses mentioned in this first version of Table 1 were subsequently revised and the Table 1 version contained in the Final Affordability Assessment Regulations contains

84 In terms of reg $23 \mathrm{~A}(15)$ of the Final Affordability Assessment Regulations a credit provider must disclose to the consumer the credit cost multiple and the total cost of credit in the pre-agreement statement and quotation; ensure that the credit cost multiple disclosures for credit facilities is based on one year of full utilisation up to the credit limit proposed; ensure that the attention of the prospective consumer is drawn to the credit cost multiple and that the cost of credit as disclosed is understood by the prospective consumer; disclose a total cost of credit which includes but is not limited to the following items: the principal debt; interest, initiation fee (if any); service fee aggregated to the life of a loan; and credit insurance aggregated to the life of a loan as set out in $\mathrm{s} 106$ of the Act. Regulation 23A(6) and (7) of the Final Affordability Assessment Regulations. 
income bands based on monthly income and refers to monthly living expenses. However, this practical explanation of how to apply Table 1 is absent from the final 2015 regulations, thus making it basically impossible for a credit provider to apply the Table without having access to the September 2013 guidelines. Even then it is uncertain whether the legislature intended that specific "formula" to apply to the use of the current Table 1 as it is not mentioned in the final regulations at all. Nowhere in the final regulations is an explanation provided of the purpose of the monthly fixed factor in the Table and exactly how the amounts in the Table should be calculated to assess the affordability of a consumer. This may create a lot of confusion and uncertainty especially for smaller, less-resourced credit providers. Other points of criticism are inter alia that the income bands and designated living expenses in Table 1 do not take into account that the profiles for consumers within a specific income may differ substantially and that this may significantly influence their living expenses; and also that the Table does not incorporate any "adversity buffer", as was indicated in the May 2013 guidelines. ${ }^{86}$ However, it should be pointed out that, with respect to the minimum living expenses as prescribed by Table 1, this does not mean that the credit provider does not have to ask the consumer to furnish information about his living expenses - the idea is that the consumer should be requested to provide details of his actual living expenses and the credit provider should take that actual amount into account - the Table only caps those living expenses at a minimum, meaning that the amount set out in Table 1 is the smallest amount that may be used for the affordability calculation unless the consumer completes the prescribed questionnaire to justify the lower expenses. However, in practice the problem may arise that credit providers are under the incorrect impression that they can use the Table alone, and do not need to assess the consumer's actual living expenses.

\subsection{Discussion and concluding remarks}

Certain pertinent aspects of pre-agreement assessment in South Africa and the context in which it is to be undertaken warrant further discussion, namely:

\subsubsection{Obligation to obtain information from the consumer in order to assess the consumer's creditworthiness}

The NCA does not expressly provide that the credit provider has to obtain information from the consumer to assess his creditworthiness and it does not provide a standard list of information to be obtained. However, it is clear from section $81(2)$ that the credit provider has to obtain information

Van Heerden and Beyers 2016 JIBLR 446-463. 
regarding the consumer's financial means, prospects and obligations. When one has regard to the definition of "financial means, prospects and obligations" in the Act it is evident that the credit provider will have to obtain information regarding the consumer's income, the regularity of such income, and also that of a person who customarily contributes to the income and shares the consumer's obligations, such as a spouse. The Final Affordability Regulations also provide an indication of the type of information that the credit provider has to assess, namely the consumer's gross income, the statutory deductions made from the income, his living expenses and his other debt obligations. Nowhere is it stated that the credit provider has to assess the consumer's assets and their value, because clearly the idea is that the consumer should be able to afford the credit without having to sell assets and that the consumer's assets are relevant solely for the purposes of collateral. Given that a consumer is usually privy to the information relating to his financial position and outlook, this means in practical terms that the credit provider will usually ask the consumer to provide information regarding his financial means, prospects and obligations during the credit application process. Section 81(4) read with Regulation 23A(6) and (7) makes it clear that the consumer has to provide complete, accurate and truthful information when requested to do so by the credit provider and must also provide authentic documentation in this regard. The Final Affordability Regulations oblige the credit provider to make a thorough assessment, as the Regulations not only prescribe the methodology for the assessment but also, in line with section $81(2)$, require the credit provider to have regard to credit bureaux information pertaining to the consumer's existing debt obligations. Although the Regulations require the credit provider to verify the consumer's gross income only, it is submitted that the consumer's salary slips will usually also reflect the relevant statutory deductions and accordingly the credit provider will also be able to verify those statutory deductions.

In so far as the verification of living expenses is concerned, it may be possible to argue that the fact that minimum living expenses are prescribed to be taken into account obviates the need for the verification of the consumer's living expenses. However, the fact that the living expenses are capped at a minimum does not mean that a credit provider is entitled to ignore a consumer's actual living expenses if he provides detail of living expenses that are greater than the prescribed minimum. In general, given that living expenses are very difficult to verify and may fluctuate, one can understand that apart from requiring that the credit provider at least make sure that the consumer's expenses are not less than the prescribed amount for his income band, the legislature does not require the credit provider to verify the consumer's living expenses. However, in order to avoid that consumers lie about their living expenses by indicating that they are lower 
than the prescribed amounts in order to obtain credit that they cannot afford or that unscrupulous credit providers manipulate the consumer's living expenses and take into account amounts less than the prescribed amounts for the consumer's income band, there is the safety net of the prescribed questionnaire that must be completed. The questionnaire reminds the consumer that he must provide the information fully (thus completely) and truthfully in order to facilitate a correct assessment. Furthermore it makes provision for the consumer's income band to be indicated on the form as well as the prescribed minimum living expense for his income band (as per Table 1) and also the lower, total amount of his living expenses as alleged by him so that it is easy to see the difference in the prescribed minimum amount and the alleged lower amount of his living expenses. Notable about this prescribed questionnaire is that it is actually a good indicator of the type of information required to be obtained in respect of the consumer's living expenses as it makes provision for accommodation, transport, food, education, medical expenses, water and electricity and maintenance. ${ }^{87}$ The obligation on a credit provider to consult credit bureaux not only enables the credit provider to ascertain the consumer's payment history and whether the consumer has used credit responsibly in the past or whether he has an inclination to default, but it also serves to verify the extent of the consumer's debt obligations. The closer to the conclusion of the agreement such a credit bureau check is done, the smaller the risk that the credit provider may have taken up other credit that is not reflected on the credit bureau records.

\subsubsection{Prohibition against providing credit}

In practical terms, with reference to section 80 of the Act, the prohibition in the NCA against reckless credit granting means that a credit provider is prohibited from granting credit to a consumer if the credit provider has not conducted a pre-agreement assessment to determine whether the consumer understands the implications of the credit that he wishes to take up and whether the consumer can actually afford the credit. However, the legislature has realised that merely requiring a pre-agreement assessment to be conducted before granting credit will not necessarily curb the possibility that the credit may propel the consumer into over-indebtedness or, where he is already over-indebted by the time that he applies for such credit, that it will not make him even more over-indebted. Therefore the result of a pre-agreement assessment will also bar a credit provider from granting credit to a specific consumer if, on a preponderance of probabilities, it appears from the assessment that the consumer lacked a general understanding of the risks and costs of the proposed credit and of

87 It is not clear exactly what the item "maintenance" in the questionnaire refers to; for example, whether it refers to maintenance payments in respect of minor children or whether it refers to items not listed above, such as clothing. 
the rights and obligations of a consumer under a credit agreement or caused him to become over-indebted (or more over-indebted).

\subsubsection{Obligation to provide information and an adequate explanation}

Given South Africa's diverse population and the high incidence of illiteracy, the NCA places priority on the right of consumers to be provided with information in plain and understandable language. ${ }^{88}$ Part B of Chapter 5 of the Act deals specifically with the disclosure requirements and section 92 specifies certain mandatory pre-agreement disclosures that must be made by the credit provider before entering into a credit agreement with a consumer. For small credit agreements these disclosures entail a preagreement statement in a prescribed (standardised) form as well as a quotation in a prescribed (standardised) form. ${ }^{89}$ For large and intermediate agreements the credit provider must also provide the consumer with a preagreement statement (here there is no prescribed form but all the information to be specified is indicated in regulation 31) as well as a quotation in the prescribed form. ${ }^{90}$ In essence the pre-agreement statement indicates how the proposed credit agreement will look, but is personalised to reflect the specific credit that the consumer wishes to take up with all its terms and conditions and so forth, whereas the quotation sets out in detail the cost of the proposed credit. ${ }^{91}$ The credit quotation provided to the consumer is binding upon the credit provider for five business days, meaning that the consumer is free to "shop around" and compare other similar credit offerings from credit providers to see if he can get a better deal elsewhere, but if he returns within 5 business days to the credit provider who provided him with the quotation, that credit provider will be bound to the interest rate and other cost of credit quoted in the aforesaid quotation. Although one can expect that in practice a credit provider will, generally upon being requested by a consumer, but sometimes also on his own initiative, explain the features of the proposed credit to the consumer, the NCA does not expressly oblige the credit provider to render such an explanation.

88 Section 64. Also see Stoop 2011 IJPL 329; Barnard 2014 J Cons \& Comm L 1, where she discusses the plain language requirement in $s 22$ of the Consumer Protection Act 68 of 2008, which is similar to the plain language provision in s 64 of the NCA. Section 92(1) read with reg 28 (pre-agreement statement and quotation for small agreements), reg 30 (prescribed form for small agreements) and forms 20 (quotation) and 20.2 (prescribed form for small agreements). Section 92(2) read with reg 29 (pre-agreement statement and quotation for intermediate or large agreements), reg 31 (requirements for intermediate or large agreements) and Form 20.1 (quotation).

91 See further s 101 regarding the cost of credit and reg 42 regarding minimum prescribed interest and initiation fees as well as reg 44 regarding service fees. 


\subsubsection{Obligation to provide advice on the suitability of credit}

The NCA places no express obligation on the credit provider to advise the consumer on the suitability of the proposed credit for his specific needs. Thus when a credit provider has furnished the consumer with the mandatory disclosure documents, namely the pre-agreement statement and quotation and, where requested to do so, has provided the consumer with an explanation regarding the features of the proposed credit, it is up to the consumer to decide whether the credit suits his needs and whether he wants to enter into the credit agreement. This choice of the consumer is of course subject to the pre-agreement assessment's having a favourable outcome.

\subsubsection{Reflection and withdrawal}

As indicated above, a consumer is given a withdrawal period of 5 business days before he enters into a credit agreement, during which the credit provider is bound to the quotation he provided in respect of the proposed credit. During this time the consumer can "reflect" on the credit by comparing the specific credit offer with other similar offers in order to eventually make an informed decision as to whether or not to take up the proposed credit. Section 121 of the NCA further provides the consumer with a cooling-off right that he can exercise in order to exit a credit agreement without breach thereof within 5 business days after the conclusion of a lease or instalment agreement that was entered into at any location other than the business premises of the credit provider. ${ }^{92}$

\subsubsection{Sanctions and remedies}

Reckless credit granting constitutes "prohibited conduct" in terms of the NCA and attracts an administrative fine by the National Consumer Tribunal. ${ }^{93} \mathrm{~A}$ credit provider may also be at risk of having its registration cancelled if it engages in reckless credit granting ${ }^{94}$ Civil remedies available to consumers to address the consequences of reckless credit granting are contained in sections 83 and 84 of the Act and in brief entail that the credit agreement can either be set aside completely or partially coupled with a "suspension". Such a suspension in essence entails that the credit

92 In terms of $\mathrm{s} 121$ a consumer may terminate a credit agreement within five business days after the date on which the agreement was signed by the consumer, by delivering a notice in the prescribed manner to the credit provider and tendering the return of any money or goods or paying in full for any services received by the consumer in respect of the agreement. For a detailed discussion see Otto "Conclusion, Alteration and Termination of Credit Agreements" para 9.5.2.

93 Section 151. Such an administrative fine may not exceed the greater of 10 per cent of the credit provider's annual turnover during the preceding financial year or R1 million.

94 Section 48. 
provider's right to enforce the reckless agreement is suspended and that he forfeits interest and other charges under the agreement for a specified time period, or where the agreement led to the consumer's over-indebtedness the remedy can be a suspension of the credit provider's rights under that credit agreement coupled with a restructuring of the consumer's other credit agreement debt. ${ }^{95}$ Whereas the administrative penalties and cancellation of licences serve to deter and punish reckless credit granting, the civil remedies not only deter reckless lending but also serve to incentivise responsible lending, whilst also remedying the ill effects of reckless credit granting. ${ }^{96}$

\section{Bibliography}

\section{Literature}

Barnard 2014 J Cons \& Comm L

Barnard $\mathrm{J}$ "In search of the 'Ordinary Consumer' and Information in Plain Language in a Multilingual, Multicultural South Africa" 2014 J Cons \& Comm $L 1-14$

\section{DTI Consumer Credit Law Reform}

Department of Trade and Industry Consumer Credit Law Reform: Policy Framework for Consumer Credit (DTI Pretoria 2004)

Kelly-Louw 2014 SA Merc LJ

95 Section 83(1) provides that despite any provision of law or agreement to the contrary, in any court proceedings in which a credit agreement is being considered, the court may declare that the credit agreement is reckless. If a court or the Tribunal declares that a credit agreement is reckless in terms of $s 80(1)$ (a) (type one reckless credit no prior credit assessment) or 80 (1)(b)(i) (type two reckless credit - the consumer did not generally understand the risks, costs or obligations under the credit agreement), the court or Tribunal has the discretion to make an order setting aside all or part of the consumer's rights and obligations under that credit agreement, as the court determines just and reasonable in the circumstances - s 83(2)(a). Alternatively, in terms of $s$ 83(2)(b), it may suspend the force and effect of that specific reckless credit agreement. In respect of the third type of reckless credit which causes the consumer to become over-indebted (as described in s 80(1)(b)(ii)), once the court or Tribunal has declared the agreement reckless it must further consider whether the consumer is over-indebted at the time of those court or Tribunal proceedings. If the consumer is still over-indebted at that time, it may make an order in terms of $s$ 83(3)(b) suspending the force and effect of that credit agreement until a date determined by it when making the order of suspension and it may further restructure the consumer's obligations under any other credit agreements. For the implications of a suspension order see $\mathrm{s} 84$.

96 For a detailed discussion see Van Heerden "Over-indebtedness and Reckless Credit" para 11.3. 
Kelly-Louw M "A Credit Provider's Complete Defence against a Consumer's Allegation of Reckless Lending" 2014 SA Merc LJ 24-59

Kelly-Louw 2015 De Jure

Kelly-Louw M "The 2014 Credit Information Amnesty Regulations: What Do They Really Entail?" 2015 De Jure 92-115

Otto "Conclusion, Alteration and Termination of Credit Agreements"

Otto JM "Conclusion, Alteration and Termination of Credit Agreements" in Scholtz JW (ed) Guide to the National Credit Act (LexisNexis Durban 2008) paras 9.1-9.5.5.2

Otto and Otto National Credit Act Explained

Otto JM and Otto R-L The National Credit Explained $4^{\text {th }}$ ed (LexisNexis Durban 2015)

Renke Evaluation of Debt Prevention Measures

Renke S An Evaluation of Debt Prevention Measures in terms of the National Credit Act 34 of 2005 (LLD-thesis University of Pretoria 2012)

Stoop 2008 De Jure

Stoop PN "Kritiese Evaluasie van die Toepassingsveld van die National Credit Act" 2008 De Jure 352-370

Stoop 2011 IJPL

Stoop PN "Plain Language and Assessment of Plain Language" 2011 IJPL 329-341

Van Heerden "Over-indebtedness and Reckless Credit"

Van Heerden C "Over-indebtedness and Reckless Credit" in Scholtz JW (ed) Guide to the National Credit Act (LexisNexis Durban 2008) paras 11.111.6

Van Heerden and Beyers 2016 JIBLR

Van Heerden C and Beyers C "Dynamic Affordability Assessment in the Context of the South African National Credit Act 34 of 2005" 2016 JIBLR 446-463

Van Heerden and Boraine 2011 De Jure

Van Heerden $C$ and Boraine A "The Money or the Box: Perspectives on Reckless Credit in terms of the National Credit Act 34 of 2005" 2011 De Jure 392-415 
Van Heerden and Renke 2015 IIR

Van Heerden $C$ and Renke $S$ "Perspectives on the South African Responsible Lending Regime and the Duty to Conduct a Pre-agreement Assessment as a Responsible Lending Measure" 2015 IIR 67-95

Wilson International Responses to Issues of Credit Wilson T (ed) International Responses to Issues of Credit and Overindebtedness in the Wake of Crisis (Ashgate Surrey 2013)

\section{Case law}

Absa Bank Ltd v Potgieter (ECPE) (unreported) case number 2344/2013 of 31 January 2017

Absa Bank v COE Family Trust 20123 SA 184 (WCC)

Beets $v$ Swanepoel (NCHC) (unreported) case number 2150/09 of 5 October 2010

Desert Star Trading 145 v No 11 Flamboyant Edleen CC 20112 SA 266 (SCA)

Friend $v$ Sendal 20151 SA 395 (GP)

Gestalt Fund Managers (Pty) Ltd v Secura Systems (Pty) Ltd 2015 JDR 1284 (GJ)

Horwood v Firstrand Bank Ltd 2011 ZAGPJHC 121 (21 September 2011)

SA Taxi Securitisation (Pty) Ltd v Mbatha 20111 SA 310 (GSJ)

Standard Bank v Hunkydory Investments 188 (Pty) Ltd 20101 SA 634 (WCC)

\section{Legislation}

Constitution of the Republic of South Africa, 1996

Consumer Protection Act 68 of 2008

Credit Agreements Act 75 of 1980

National Credit Act 34 of 2005

National Credit Amendment Act 19 of 2014

Usury Act 73 of 1968 


\section{Government publications}

GN 713 in GG 28893 of 1 June 2006

GN R597 in GG 37882 of 1 August 2014

GN R202 in GG 38557 of 13 March 2015

GN 756 in GG 39127 of 21 August 2015

\section{Internet sources}

Goodwin-Groen and Kelly-Louw 2006 http://www.finmark.org.za/wpcontent/uploads/2016/01/Rep_NCA_AccesstoFinance_2006.pdf

Goodwin-Groen RP and Kelly-Louw M 2006 The National Credit Act and Its Regulations in the Context of Access to Finance in South Africa http://www.finmark.org.za/wp-

content/uploads/2016/01/Rep_NCA_AccesstoFinance_2006.pdf accessed 1 November 2015

Minister of Trade and Industry 2005 http://www.gov.za/ sites/www.gov.za/files/b18-05_0.pdf

Minister of Trade and Industry 2005 Memorandum on the Objects of the National Credit Bill, 2005 http://www.gov.za/sites/www.gov.za/files/b1805_0.pdf accessed 11 April 2017

Ministry of Finance 2012 http://www.treasury.gov.za/comm_media/press/ 2012/2012110101.pdf

Ministry of Finance 2012 Joint Statement - Ensuring Responsible Market Conduct for Bank Lending http://www.treasury.gov.za/comm_media/press/ 2012/2012110101.pdf accessed 9 October 2015

NCR 2010 http://www.ncr.org.za/pdfs/Circulars/Code\%20of\%20Conduct\% 20for\%20CPs.pdf

National Credit Regulator 2010 Credit Provider's Code of Conduct to Combat Over-indebtedness http://www.ncr.org.za/pdfs/Circulars/Code\%

20of\%20Conduct\%20for\%20CPs.pdf accessed 5 August 2015

NCR 2013 http://www.ncr.org.za/press_release/Public\%20Notice\%20.pdf National Credit Regulator 2013 Press Release http://www.ncr.org.za/press_release/Public\%20Notice\%20.pdf accessed 5 August 2015

September 2013 http://debtfreedigi.co.za/wp-content/uploads/2013/ 10/NCR-AffordabilityAssessmentGuidelines.pdf accessed 5 August 2015 
September 2013 Affordability Assessment Guidelines http://debtfreedigi.co.za/wp-content/uploads/2013/10/NCR-

AffordabilityAssessmentGuidelines.pdf accessed 5 August 2015

World Bank 2013 Siteresources.worldbank.org/.../Resources/.../ Responsible-Lending-Paper.pdf

World Bank 2013 Report on responsible lending - overview of regulatory tools - October Siteresources.worldbank.org/.../Resources/ResponsibleLending-Paper.pdf accessed 12 April 2017

\section{List of Abbreviations}

BASA

DTI

EU

IIR

IJPL

J Cons \& Comm L

JIBLR

NCA

NCR

SA Merc LJ
Banking Association of South Africa

Department of Trade and Industry

European Union

International Insolvency Review

International Journal of Private Law

Journal of Consumer and Commercial

Law

Journal of International Banking and

Regulation

National Credit Act

National Credit Regulator

South African Mercantile Law Journal 